\title{
"EU QUERO APRENDER A FALAR": O ESTUDO DOS GÊNEROS ORAIS NA AULA DE LÍNGUA PORTUGUESA
}

\section{"I WANT TO LEARN TO SPEAK": THE STUDY OF ORAL GENRES IN A PORTUGUESE LANGUAGE CLASS}

Rosana Dutra de Sousa ${ }^{9}$

Clara Dornelles ${ }^{10}$

\begin{abstract}
RESUMO: Este estudo buscou compreender como tratar a oralidade como objeto de ensino nas aulas de Língua Portuguesa (LP) na escola. O projeto foi desenvolvido como uma pesquisa-açăo durante o Estágio Curricular em LP, noprimeiro ano do ensino médio, em uma escola pública da cidade de Bagé (RS). De cunho qualitativo, a pesquisa se configura como pesquisa-açăo (LATORRE, 2003) em Linguística Aplicada e utiliza suporte teórico-metodológico da Sociolinguística Interacional (RIBEIRO; GARCEZ, 1998) e da Microetnografia Escolar (ERICKSON; SCHULTZ, 1998) para geraçâo e análise de dados. Os instrumentos de pesquisa incluíram filmagem das aulas e produçăo de diário reflexivo. A partir das filmagens, foram gerados excertos que săo problematizados para (i) analisar como se deu o processo de apropriaçăo dos gêneros orais secundários (entrevista e seminário); (ii) investigar se um projeto de ensino pautado no estudo desses gêneros favorece a legitimaçăo da oralidade como objeto de ensino. Os resultados obtidos na pesquisa demonstram como o estudo sistemático dos gêneros orais secundários contribuiu no processo de apropriaçăo desses gêneros, especialmente acionando a reflexăo dos alunos sobre elementos linguísticos e paralinguísticos. Mostram também a importância que um projeto de ensino pautado no estudo sistemático dos gêneros orais tem para favorecer a legitimar a oralidade como objeto de ensino na escola.
\end{abstract}

Palavras-chave: Oralidade; pesquisa-açăo; ensino; microetnografia.

ABSTRACT: This study aimed to understand how to analyze and treat the oral speech as a teaching object in Portuguese classes. The project was developed as an action research during the Curricular Training in Portuguese in the $1^{\text {st }}$ year of high school, in a public institution located in Bagé (RS). The methodology used is action-research

9 Possui graduaçâo em Letras (Português e Respectivas Literaturas) pela Universidade Federal do Pampa (Unipampa), Campus Bagé (RS).E-mail: rosanads.24@hotmail.com.

10 Possuigraduaçáo em Letras pela Universidade Federal de Santa Catarina(UFSC), Mestrado em Linguística Aplicada pela mesma instituiçáo e Doutorado em Linguística Aplicada pela Universidade Estadual de Campinas (Unicamp). E Professora Associada da Universidade Federal do Pampa (Unipampa), onde atua no curso de Letras/Línguas Adicionais e no Mestrado Profissional em Ensino de Línguas. E-mail: claradornelles@gmail.com. 
(LATORRE, 2003), in a qualitative perspective in Applied Linguistics, and interactional sociolinguistics (RIBEIRO; GARCEZ, 1998) and microethnography (ERICKSON; SCHULTZ, 1998) are used as theoretical-methodological supports to generate the data. The sources used for the data development included video recordings of the classes and the production of a reflective journal. The video recordings generated excerpts which are problematized to (i) analyze the process of appropriation of secondary oral genres (interview and seminar); (ii) investigate if a teaching project based on the study of these genres could legitimate orality as teaching objects. The results demonstrate that the study of secondary oral genres as a teaching object contributed to the appropriation of these genres, specially raising students" awareness about linguistic and paralinguistics resources. Besides, the study shows the importance of an education project that sistematically guides the study of oral genres to legitimate orality as a teaching object.

Keywords: orality; action-research; teaching; microethnography.

\section{INTRODUÇÃO}

O presente estudo busca responder a questáo de como tratar a oralidade como objeto de ensino na aula de Língua Portuguesa (LP) na escola regular. Para realizar esse propósito, desenvolveu-se um projeto em que a importância de trabalhar a oralidade foi reforçada pelo pedido de um dos alunos: "eu quero aprender a falar". Esse pedido fez surgir muitas indagaçôes e reflexóes acerca de como o ensino da oralidade está sendo tratado na escola. Quando um aluno cursando o ensino médio chega à conclusâo de que năo sabe falar, parece-nos que a escola năo está contemplando elementos e dimensóes relevantes do estudo de LP. A observaçăo do aluno nos provocou a articular uma proposta de ensino ao desenvolvimento de uma pesquisa-açâo que buscasse gerar dados para investigar e intervir no processo de apropriaçăo de gêneros orais secundários. 0 contexto de ensino e pesquisa foi uma turma deprimeiro ano do ensino médio, no turno da manhá, em uma escola da rede pública estadual da cidade de Bagé (RS). Como os alunos precisavam desenvolver um seminário por solicitaçấo da escola, associamos em nossa pesquisa-açăo o estudo do gênero seminário e de um gênero que pudesse gerar, via pesquisa, dados relevantes para a apresentaçâo oral, a entrevista.

Marcuschi (2001, p. 37) diz: "o homem pode ser definido como um ser que fala e năo como um ser que escreve". O autor ao definir o homem como um ser que fala e náo como um ser que escreve, permite-nos refletir sobre a importância da fala e os papéis que os falantes assumem na interlocuçăo. Ao assumirem esses papéis, tanto nas esferas privadas ou públicas, é essencial que o falante selecione a linguagem adequada ao contexto de uso. Embora a fala se aprenda naturalmente, năo se aprende naturalmente a escolha de como utilizar a linguagem em contextos específicos.

A partir do estudo dos gêneros, as políticas de ensino de LP trouxeram uma nova perspectiva didática, que visa, sobretudo, possibilitar o desenvolvimento da capacidade interativa dos sujeitos (BRASIL, 1997, 2002). Ao privilegiar a língua na concepçâo de interaçấo social, segundo a qual os gêneros estâo vinculados às diferentes atividades da esfera humana (Cf.: BAKHTIN, 2000), a escola constitui-se como mediadora desses 
discursos, trazendo para a sala de aula a língua em uso. Contudo, a escola legitima o ensino da escrita em detrimento do ensino da fala. Os Parâmetros Curriculares Nacionais (PCNs) do Ensino Médio (BRASIL, 2002, p. 70) afirmam que: "pensar o ensino de Língua Portuguesa no ensino médio significa dirigir a atençăo năo só para a literatura ou para a gramática, mas também para a produçâo de textos e a oralidade". Nesse sentido, entendemos que é necessário valorizar a oralidade como objeto de ensino e buscar modos de investigar a apropriaçăo dos gêneros orais no percurso da aprendizagem.

De cunho qualitativo, esta pesquisa se configura como uma pesquisa-açâo (LATORRE, 2003) em Linguística Aplicada (SIGNORINI, 1999) e utiliza suporte teórico-metodológico da Sociolinguística Interacional (GARCEZ; RIBEIRO, 1998) e da Microetnografia Escolar (ERICKSON; SCHULTZ, 1998) para geraçăo e análise de dados que priorizam a filmagem da interaçăo face a face. As tradiçôes de pesquisa da interaçăo se configuram como meios de desvendar açōes sociais em diferentes contextos, entre eles o espaço escolar, por meio da análise das açōes situadas dos participantes, ou seja, do que está acontecendo no momento específico de fala. A partir das filmagens, foram gerados excertos que sâo problematizados para (i) analisar como se deu o processo de apropriaçăo dos gêneros orais secundários (entrevista e seminário); (ii) investigar se um projeto de ensino pautado no estudo desses gêneros favorece a legitimaçáo da oralidade como objeto de ensino.

Para a definiçâo dos procedimentos metodológicos, associamos a pesquisa-açáo à pesquisa microetnográfica, tendo como referência Erickson e Shultz (2013). O trabalho está organizado da seguinte forma: na primeira parte, o referencial teórico, que traz as referências teóricas adotadas; na segunda parte, a metodologia utilizada na pesquisa e o contexto de pesquisa; e, por último, a análise de dados, demonstrando como a discussáo acerca da oralidade em sala de aula foi compreendida pelos estudantes e como perceberam esse processo. Assim, buscamos demonstrar como a importância de um projeto de ensino pautado no estudo dos gêneros orais pode favorecer a legitimar a oralidade como objeto de ensino.

\section{GÊNEROS ORAIS NO ENSINO}

As orientaçóes para o ensino da oralidade têm chegado à escola por meio dos livros didáticos. Porém, muitas vezes, esses materiais11 propóem atividades para a participaçăo oral dos estudantes sem contemplar a análise da estrutura composicional e estilística do gênero produzido e/ou de suas condiçōes de produçăo e recepçăo.

Ao propor o trabalho com gêneros orais, em sala de aula, é relevante reconhecer que transformar a oralidade (suas práticas e gêneros) em objeto de ensino ultrapassa o exercício da comunicaçăo oral, pois é necessário refletir sobre como utilizar a variedade de usos da língua na modalidade oral e, com isso, explorar os aspectos linguísticos associados aos sociodiscursivos (BENTES, 2010). De acordo com os PCNs, "eleger a língua oral como conteúdo escolar exige o planejamento da açăo pedagógica de forma

11 A coleçâo Viva português: ensino médio de Elizabeth Campos, Paula Marques e Sílvia Letícia de Andrade, guia 2015/2017 do Plano Nacional do Livro Escolar (PNLD), aborda o estudo dos gêneros orais e escritos como objeto de ensino. 
a garantir, na sala de aula, atividades sistemáticas de fala, escuta e reflexăo sobre a língua" (BRASIL, 1997, p. 38). Portanto, é necessário que os alunos sejam conscientizados de que tomar a palavra é uma atividade importante e complexa, pois amplia a competência comunicativa, a sua formaçăo intelectual e crítica dentro da escola e no meio social.

Mas, para isso, é preciso fornecer e oportunizar aos alunos instrumentos para observaçâo e análise de práticas orais, fornecer os contextos, as motivaçōes e as finalidades para o exercício dessas práticas, tanto na sala de aula como fora dela (BENTES, 2010). Se nos comunicamos através de gêneros, é necessário que a escola traga essa reflexáo e esse estudo para a sala de aula e o professor desempenhando o papel de mediador, transforme essa reflexăo em objeto de ensino.

Na concepçăo bakhtiniana, utiliza-se para designar os gêneros primários săo considerados tipos de comunicaçăo verbal espontânea, ao contrário dos secundários, que implicam a necessidade de uma intervençâo para o processo de desenvolvimento. Esses gêneros săo mediados pela leitura/escrita, exigem um domínio de relaçôes formais e mais complexas e o ensino possibilita o desempenho dessa açâo. Assim, o estudo dos gêneros secundários prepara o sujeito para agir fora do seu contexto cotidiano e escolar, passando para uma esfera de relaçóes complexas, que precisam ser construídas para agir no mundo muitas vezes ainda náo conhecido. Deve-se levar em consideraçăo, que os gêneros secundários podem ser também orais, por isso a necessidade de incluí-los como objeto de ensino (SCHNEUWLY; DOLZ, 2010). Sejam primários ou secundários, os gêneros orais sâo também estruturados por regras sociodiscursivas e linguísticas.

Na proposta de trabalho didático que serviu de corpus desta pesquisa, foram estudados os gêneros discursivos pautados pelos fundamentos teóricos bakhtinianos, que concebem a língua como interaçăo. Dentre os diversos gêneros secundários, os escolhidos foram os gêneros entrevista e seminário, por serem gêneros que circulam na esfera pública e săo esses que devem ser ensinados na escola.

Segundo a teoria dos gêneros do discurso, sempre que falamos ou escrevemos, recorremos a um determinado gênero, ou seja, elegemos o enunciado de acordo com a situaçăo comunicativa que pretendemos. Ao propor esse estudo, permite-se uma reflexăo sobre a concepçăo de língua pautada nos gêneros, pois se é através deles que empreendemos a comunicaçâo verbal, podemos utilizar desse recurso para o estudo da língua e, assim, fazer uma relaçâo com o uso. Bakhtin (2000, p. 302) nos explica como se dá essa construçâo nos gêneros do discurso:

Os gêneros do discurso organizam nossa fala da mesma maneira que a organizam as formas gramaticais (sintáticas). Aprendemos a moldar nossa fala às formas do gênero e, ao ouvir a fala do outro, sabemos de imediato, bem nas primeiras palavras, pressentir-lhes o gênero, adivinhar-lhe o volume (a extensăo aproximada do todo discursivo), a dada estrutura composicional, prever-lhe o fim [...]. Se năo existissem os gêneros do discurso e se náo os denominássemos, se tivéssemos de criá-los pela primeira vez no processo da fala, se tivéssemos de construir cada um de nossos enunciados, a comunicaçâo verbal seria quase impossível.

Essa concepçâo bakhtiniana nos mostra a existência da pluralidade de gêneros, tanto orais como escritos, e que é através deles que nos comunicamos e interagimos. Autores como Dolz e Gagnon (2015), que trazem o aporte teórico de Bakhtin, nos dizem 
que cada esfera de utilizaçăo da língua elabora enunciados relativamente estáveis e sâo esses tipos relativamente estáveis que constituem os gêneros do discurso. Portanto, a constituiçăo desses gêneros funciona como uma norma que intervém tanto na estruturaçâo dos enunciados como nas formas da linguagem. De acordo com Bakhtin (1984), há uma relaçâo entre os gêneros primários e secundários, sendo que os segundos absorvem e transformam os primeiros, deixando de ter uma relaçăo imediata com o real existente e com os demais enunciados.

Ao levar o estudo dos gêneros orais como objeto de ensino para a escola, coloca-se fala e escrita no mesmo status de importância. Com essa prática buscamos desmistificar a superioridade da escrita em relaçấo à fala no ensino de LP. É preciso que se compreenda que fala e escrita náo se opóem ${ }^{12}$, sâo práticas discursivas que se completam e nâo possuem diferenças essenciais. Portanto, dependendo da situação comunicacional, no caso do gênero entrevista e seminário, utiliza-se também da escrita como apoio.

Conforme já enfatizado, os gêneros caracterizam-se de acordo com a atividade sociodiscursiva a que servem. Sendo assim, ao utilizarmos um determinado gênero conhecemos a forma e objetivos específicos dessas situaçōes particulares. Para tanto, autores apontam que a apropriaçăo dos gêneros é um processo fundamental de socializaçăo, pois, é através desse processo de apropriaçấo que os indivíduos se tornam capazes de refletir e agir produtivamente e positivamente na sociedade (MATENCIO, 2008). Portanto, utilizar-se dos gêneros como ferramenta para a prática do ensino de LP possibilita aos indivíduos a apropriaçăo de competência linguística, comunicativa e discursiva.

A competência linguística refere-se à capacidade de usar conscientemente as diversas estruturas da língua. Diferentemente, a competência comunicativa diz respeito à capacidade de utilizar os enunciados da língua em situaçôes concretas de comunicaçăo. E, por fim, a competência discursiva é entendida como o conjunto das formas específicas para estabelecer a significaçăo, ou seja, os sentidos que estâo em funcionamento em um recorte sócio-histórico-ideológico de uma sociedade e cultura (Cf.: TRAVAGLIA, 2015).

Sabe-se da diversidade de gêneros orais, por isso, alguns autores recomendam que a escolha desses gêneros para o ensino deva recair nos gêneros orais públicos. Autores como Schneuwly e Dolz (2010) preconizam a necessidade de incluir os gêneros orais como objeto de ensino na escola e como um dos eixos do currículo escolar. Conforme esses autores, os gêneros orais passam a ser, ao mesmo tempo, um instrumento de comunicaçâo e um objeto de aprendizagem.

O estudo dos gêneros orais da comunicaçăo pública formal permite que os estudantes se utilizem de recursos da língua de forma mais consciente e reflexiva. Esse estudo possibilita a seleçấo e utilizaçáo desses gêneros em diferentes contextos, dependendo do grau de formalidade e das exigências das instituiçóes onde se realizam. Um aspecto a ser observado é que em situaçôes comunicativas orais, sejam elas a distância ou face

12 As modalidades oral e escrita sâo vistas como práticas sociais, já que o estudo das línguas se funda em usos. A oralidade e a escrita sâo práticas e usos da língua com especificidades e condiçôes distintas de realizaçăo, mas nâo suficientemente opostas para caracterizar dois sistemas linguísticos (MARCUSCHI, 2001). 
a face, formais ou informais, planejadas ou improvisadas, ao nos comunicarmos pela oralidade, năo apenas falamos, mas fornecemos ao outro um vasto conjunto de informaçōes sobre várias facetas de nossas identidades sociais e sobre a maior ou menor amplitude de nossa competência comunicativa (BENTES, 2010). Portanto, através da comunicaçăo oral é possível identificar a que grupo social a ou o falante pertence, sua idade, gênero e escolaridade, logo, a linguagem relaciona-se com a história, à sociedade e à cultura.

\section{GÊNERO ORAL ENTREVISTA}

O gênero entrevista corresponde a um meio de obter informaçóes, de um assunto ou de alguém, através de perguntas e respostas. Esse gênero é considerado como macrogênero por alguns autores, por entenderem que o gênero entrevista é uma constelaçăo de eventos possíveis, que se realizam como gêneros (ou subgêneros) diversos. Pode-se citar como exemplo a entrevista jornalística, a médica, a de trabalho, a de emprego.

O macrogênero entrevista possui elementos comuns a todos os subgêneros como: sua estrutura sempre se caracteriza por perguntas e respostas - o entrevistador e o entrevistado; o papel que o entrevistador desempenha, que se caracteriza por abrir e fechar a entrevista, fazer perguntas, introduçăo de assuntos novos, (re)orientar a interaçăo; o entrevistado desempenha a funçăo de responder e fornecer as informaçôes solicitadas. Um subgênero diferencia-se do outro pelas características que estâo relacionadas com o objetivo, a natureza, o público-alvo, a apresentaçăo, o fechamento, a abertura e o tom de formalidade, entre outros aspectos definidos pela situaçáo de comunicaçăo (MELO; MARCUSCHI; CAVALCANTE, 2012).

O estudo do gênero oral entrevista possibilita-nos desfazer a polarizaçăo entre fala e escrita, trazendo a compreensăo de que as duas modalidades nâo se opóem, mas completam-se e nesse gênero evidencia-se a relaçáo entre elas. Entre os subgêneros podemos citar uma entrevista jornalística para um programa de rádio e uma entrevista jornalística para um jornal impresso. No ensino, podemos promover situaçóes de análise das esferas em que esses gêneros circulam, suas finalidades e as interaçôes que sâo estabelecidas através desses gêneros. A importância em perceber essas especificidades entre os subgêneros possibilita-nos diferentes situaçôes didáticas de ensino desse gênero. Assim, os diferentes tipos de entrevistas podem servir para o desenvolvimento de atividades didáticas na esfera escolar, observando-se que necessidade de adequaçăo há para que os objetivos escolares sejam atingidos (LEAL; SEAL, 2012).

O gênero entrevista foi um dos gêneros escolhidos para ser estudado, constituindo-se como instrumento de coleta de dados13 e como fonte de informaçăo para a produçâo de outro gênero oral, o seminário. Entre as características a serem observadas nessa entrevista temos: a) o número de participantes envolvidos, no caso específico, a presença de vários entrevistadores para um entrevistado, que condiciona uma maior

13 As autoras consideram, neste caso, a entrevista como instrumento de coleta de dados, náo especificando o subgênero. Assim, podemos usar entrevistas em atividades de pesquisa científica, pesquisa de opiniâo, pesquisa de tendências de consumo, entre outras. Dizem que o domínio dos gêneros orais secundários relacionados aos espaços de trabalho, no caso, o espaço escolar, săo necessários à apropriaçáo pelos estudantes, visando atender as necessidades práticas relacionadas diretamente ao seu cotidiano (LEAL; SEAL, 2012). 
ou menor possibilidade de mudança de falantes e o tempo da fala de cada um; b) o nível de conhecimento dos participantes entre si e o grau de cooperaçăo de cada um, possibilitando uma maior quantidade de conhecimento partilhado; c) o envolvimento dos participantes um com o outro, com o assunto e com a situaçăo; e d) o grau de espontaneidade das falas, indicando um maior ou menor nível de planejamento das perguntas ou intervençóes que pode sinalizar uma conversa mais formal ou informal (MELO, MARCUSCHI; CAVALANTE, 2012). A escrita serviu de apoio para a realizaçăo da entrevista, pois os entrevistadores haviam elaborado um roteiro de perguntas, que no momento da interaçâo face a face foi modificado, devido ao engajamento dos participantes com o assunto e com a situaçăo. As anotaçóes realizadas durante a entrevista serviram como subsídio de pesquisa para os estudantes na produçâo do gênero seminário.

\section{GÊNNERO ORAL SEMINÁRIO}

Schneuwly e Dolz (2010, p. 185) afirmam que:

[... ] podemos, pois definir a exposiçăo oral ${ }^{14}$ como um gênero textual público, relativamente formal e específico, no qual um expositor especialista dirige-se a um auditório, de maneira (explicitamente) estruturada, para lhe transmitir informaçóes, desc rever-lhe ou lhe explicar alguma coisa.

Segundo esses autores, a exposição oral é um gênero público, formal e específico, portanto, é um gênero secundário e sâo esses que devem ser ensinados na escola. Tem como característica um expositor, que assume a condiçăo de especialista, que se dirige a um público para transmitir informaçóes. Informaçôes essas que devem ser organizadas e estruturadas pelo expositor, que tem o papel de informar, descrever e explicar o assunto, ou seja, modificar o conhecimento da plateia em relaçăo ao objeto de estudo apresentado.

Ao trazer a exposiçăo oral ${ }^{15}$ para a escola e transformá-la em objeto de ensino, é preciso observar as características desse gênero, que objetivos pretendemos e que intervençóes pedagógicas utilizaremos para isso. Esse gênero é considerado público e formal, portanto, exige que o expositor ao o apresentar siga um planejamento e uma organizaçấo adequada ao gênero. Para tanto, esse expositor deve proceder a uma pesquisa, selecionar as ideias principais das secundárias garantindo coerência em relaçâo à temática. Além disso, o gênero exige uma ordenaçăo de sua forma composicional que permite distinguir as fases de sua construçâo interna. Distinguimos as seguintes partes em uma apresentaçâo oral: a fase de abertura, de introduçâo ao tema, a apresentaçáo do plano da exposiçâo, o desenvolvimento e o encadeamento dos diferentes temas, a recapitulaçăo e síntese, a conclusâo e o encerramento (SCHNEUWLY; DOLZ, 2010).

Ao transformar a oralidade em objeto de ensino, é necessário fornecer ao aluno formas que permitam construir operaçōes linguísticas específicas que caracterizam esse

\footnotetext{
14 Segundo Dolz e Schneuwly (2010), a exposiçăo oral é frequentemente denominada e utilizada na escola com a terminologia de seminário.

15 Cf.: GOMES-SANTOS (2012).
} 
gênero de texto ${ }^{16}$. No gênero exposiçăo oral, denominado seminário no ambiente escolar, podemos citar, entre outras operaçôes linguísticas: a coesăo temática que articula as diferentes partes e sinaliza no texto quais săo as ideias principais e as secundárias, o desenvolvimento das conclusóes resumidas e das sínteses. Para que isso ocorra, é necessário que os estudantes percebam a importância de marcadores de estruturaçâo do discurso, de organizadores temporais e dos tempos verbais (SCHNEUWLY; DOLZ, 2010).

Sendo assim, a escola ao trazer o estudo dos gêneros secundários orais possibilita aos estudantes apropriarem-se de competências linguística, comunicativa e discursiva, com isso, demonstrando a importância que o domínio da palavra pública oral exerce na sociedade.

\section{METODOLOGIA}

Esta pesquisa está inserida na área da Linguística Aplicada de cunho transdisciplinar (SIGNORINI, 1999) e associada à Sociolinguística Interacional (RIBEIRO; GARCEZ, 1998) e, portanto, assume a perspectiva da língua em uso e da abordagem qualitativa (LÜDKE; ANDRÉ, 1986). Desse modo, interessa-nos a interaçâo como objeto de estudo, e essa interaçăo é situada no tempo e no espaço específicos em que é construída por seus participantes. Em nosso caso, no espaço de sala de aula de língua portuguesa em uma escola brasileira do interior do RS, em uma experiência de estágio curricular de um curso de Letras.

Como procedimento técnico e método, escolhemos a pesquisa-açăo (Cf.: DIONE, 2007), que consiste basicamente em resolver problemas sociais e técnicos, através de grupos de pesquisadores. Esse método pode ser compreendido como "um caminho ou um conjunto de procedimentos para interligar conhecimento e açăo, ou extrair da açáo novos conhecimentos" (THIOLLENT, 2011, p. 8). Para Latorre (2003, p. 24), no campo do encino, "la investigación-acción es vista como una indagación práctica realizada por el profesorado, de forma colaborativa, con la finalidad de mejorar su práctica educativa a través de ciclos de acción y reflexión".

A partir da definiçấo apresentada, compreendemos a pesquisa-açăo como um método que visa a uma açáo interventiva com a finalidade de melhorar a prática. Para que isso ocorra, é necessário que o professor reflita sobre três pontos, que săo: a pesquisa, a açăo e a formaçăo, ${ }^{17}$ relacionando-os com sua prática (LATORRE, 2003). A motivaçáo deste projeto de pesquisa náo foi mudar o sistema de ensino, porque se encontra fora do alcance pessoal, mas a prática do professor. É pensar como eu/professora participante do processo de ensino-aprendizagem reflito criticamente sobre minha açăo e que métodos săo utilizados para aprimorar minha prática.

16 ROJO (2005, p. 185) diz: "[...] na teoria dos gêneros do discurso - centra-se, sobretudo no estudo das situaçôes de produçấo dos enunciados ou textos em seus aspectos sócio-históricos [...] e teoria dos gêneros de textos - na descriçăo da materialidade textual". Nesta pesquisa, mantemos os conceitos de acordo com o uso feito pelos autores consultados, mas a nossa preocupaçăo maior, no trabalho pedagógico, foi com a dimensâo da materialidade textual, embora sempre em articulaçăo com as condiçôes de produçăo e recepçáo.

17 As palavras pesquisa, açăo e formaçăo fazem referência ao Triângulo de Lewin (1946), que diz que os vértices do ângulo devem permanecer unidos em benefício dos seus três componentes (grifos e traduçáo nossos). 
Com o objetivo de buscar instrumentos metodológicos para a açăo interventiva, com a finalidade de melhorar a prática, articulamos pesquisa-açăo e microetnografia. Esta tradiçâo de pesquisa busca compreender situaçōes e comportamentos que ocorrem em interaçôes cotidianas ou institucionais, principalmente em instituiçôes escolares. Para análise dessas interaçóes, é necessária a compreensăo de contexto emergente na própria interaçáo, nâo só em decorrência das pistas fornecidas pelo ambiente físico e social, mas pelas informaçóes contidas pelo que as pessoas fazem a cada momento de uma conversaçăo e por onde e quando elas fazem o que fazem (ERICKSON; SHULTZ, 1998).

Erickson e Shultz (1998) sistematizaram os procedimentos de análise de dados interacionais que precisam ser gravados, preferencialmente, em vídeo e que devem ser analisados em seis momentos, na seguinte ordem: (1) assistir à filmagem por inteiro, parando muito de vez em quando, anotando as principais ocasióes; (2) buscar ocasióes importantes para observaçáo detalhada; (3) identificar as diferenças na estrutura de participaçăo no âmbito das articulaçóes; (4) transcriçaáo da fala e dos gestos, dependendo da necessidade, com o propósito de construçăo de um modelo descritivo; (5) testar e validar o modelo de estrutura da interaçáo, com o interesse em demonstrar a relevância contrastiva, para os participantes, das pistas de contextualizaçấo nas articulaçôes elementares de uma ocasiâo interacional; e (6) estabelecer a possibilidade de se generalizar a análise, procedendo a um levantamento de nosso corpus, buscando ocorrências análogas do tipo de ocasiâo que estejamos investigando.

\section{CONTEXTO E PROBLEMA DE PESQUISA}

O desenvolvimento do projeto de pesquisa-açáo ocorreu em uma escola da rede pública estadual, localizada em um bairro na cidade de Bagé (RS). A turma era composta por quarenta estudantes, cursando o primeiro ano do ensino médio, no turno da manhă, e a disciplina de LP tinha uma carga horária de 4 h/a semanais. As observaçóes das aulas demonstraram que as práticas de ensino de LP estâo centradas no normativismo das gramáticas tradicionais e em um estudo fragmentado de LP, năo levando em consideraçăo o uso da língua. Os estudantes que compóem a turma săo bastante heterogêneos em relaçăo ao nível socioeconômico. Além disso, alguns estudantes residiam na zona rural, o que diversificava ainda mais a turma.

O projeto foi desenvolvido no período de março a junho de $2015 .{ }^{18} \mathrm{Na}$ atividade diagnóstica, um dos estudantes manifestou a vontade de aprender a "falar", dizendo: "eu quero aprender a falar", e outros disseram que gostariam de aulas mais práticas. A partir de conversa informal com a turma, percebemos que o que eles queriam era aprender a usar a oralidade em seus diferentes contextos. Sendo assim, a problemática a ser compreendida e solucionada estava vinculada ao ensino da oralidade. Por isso, optamos por tratar da apropriaçáo de gêneros orais secundários.

As atividades desenvolvidas na escola, no período da experiência docente, estavam vinculadas a um projeto cujo tema era o "trabalho". Nas aulas de LP, a proposta de ensino se organizou em torno do estudo dos gêneros orais entrevista e seminário para realizar uma "Feira das Profissōes", que se desenvolveu da seguinte forma: divisăo dos

18 A disciplina de Estágio Curricular III foi orientada pela Prof. ${ }^{\text {a }}$ Dr. ${ }^{\text {a }}$ Isabel Cristina Teixeira, enquanto paralelamente discutia sobre pesquisa-açăo com a orientadora de TCC. 
estudantes em grupos, escolha das profissóes, pesquisa de material bibliográfico e realizaçâo de entrevistas pelos estudantes com uma psicóloga, uma estudante de técnico em agropecuária e um militar. O resultado da pesquisa dos estudantes e das entrevistas ajudaram a compor o seminário apresentado no final do projeto. Buscou-se assim ensinar a oralidade como prática social e investigar se um projeto de ensino pautado no estudo desses gêneros favorece a legitimaçấo da oralidade como objeto de ensino.

\section{CRITÉRIOS DE SELEÇÃO E ANÁLISE DE DADOS}

Os instrumentos de geraçăo de dados utilizados para análise foram: atividade diagnóstica ( $2 \mathrm{~h} / \mathrm{a})$, filmagem das aulas (gravaçôes em vídeo, totalizando 15 h/a), autoavaliaçăo (1 h/a), diário reflexivo e anotaçôes de campo. Foi solicitado aos responsáveis pelos estudantes a assinatura de um Termo de Consentimento para utilizar os dados gerados na pesquisa.

A análise dos dados se deu pela revisitaçăo detalhada de gravaçôes em vídeo das aulas. Os objetivos foram analisar como se deu o processo de apropriaçáo dos gêneros orais secundários e investigar se um projeto de ensino pautado nos gêneros orais pode favorecer a legitimar a oralidade como objeto de ensino e a pensar em práticas de ensino que possam levar a uma melhor compreensão desses gêneros.

Os dados considerados relevantes para a pesquisa-açăo serăo apresentados e analisados numa sequência de tempo e de como se deu a apropriaçâo dos gêneros orais registrados nas aulas de LP. Para tanto, serâo utilizados excertos de fala em interaçấo, com descriçăo baseada na geraçáo de dados realizada.

O apoio metodológico utilizado está baseado na microetnografia que, como mencionado anteriormente, nos fornece orientaçōes para observaçâo minuciosa e sistemática da interaçăo social. Através dessa observaçăo e revisitaçăo do material audiovisual é que se deu a percepçáo de como a discussâo acerca da oralidade é compreendida pelos estudantes em sala de aula.

Além de gravaçōes em áudio e vídeo, que ocorreram com câmera parada durante o período das aulas, a análise dos dados também se utilizou dos recursos: diário reflexivo e anotaçóes de campo. A descriçăo da geraçăo de dados se deu a partir dessas gravaçóes e pela segmentaçăo, revisitaçấo e transcriçăo detalhada de fala-em-interaçấo, que considerou os demais dados gerados. A transcriçấo de dados é um processo seletivo, pois busca demonstrar aspectos interacionais, de acordo com metas investigativas específicas, que vâo ao encontro do objetivo da pesquisa. Autores como Garcez, Bulla e Loder (2014) nos dizem que náo há transcriçăo perfeita, em relaçăo à captura de toda a situaçăo original, mas há transcriçôes que representam as informaçōes de forma mais consistentes com as metas descritivas e teóricas. Para a transcriçâo de dados, foi utilizada a tabela de convençôes de Jefferson, conforme Loder (2008), e disponibilizada de modo sintético no Anexo I, deste artigo.

\section{ANÁLISE DOS DADOS}

Os excertos aqui apresentados săo problematizados no intuito de demonstrar como a proposta de ensino de gêneros orais se concretizou na sala de aula e de avaliar o trabalho realizado, tendo em vista, de um lado, o processo de apropriaçáo dos gêneros 
entrevista e seminário pelos estudantes, e, de outro, a viabilidade de promover a legitimaçăo dos gêneros orais como objeto de ensino na escola. $O$ primeiro excerto ilustra o modo como tudo começou.

\section{A CONSTRUÇÃO DA ORALIDADE COMO OBJETO DE ENSINO}

\section{Fragmento 1 - Excerto ${ }^{19}$ de transcriçăo da aula do dia 26 de maio.}

01 Professora: vamos trabalhar a respeito dos gêneros do discurso. eu já tinha feito uma introdução a respeito disso. Alguém lembra o que são gêneros.

02 Cândida: a gente não lembra de nada. hhhh

03 Professora: quando nós nos comunicamos. o que estamos fazendo. quando eu falo com a Estela

04 Cândida: com a Cândida

05 Professora: Cândida desculpa. o que estamos fazendo,

06 Cândida: dialogando

07 Professora: dialogando. muito bem. e esse diálogo é o que. $(2,3)$ é um gênero. então o que é que é gê: : nero $(2,3)$

08 Gustavo: um diálogo

09 Professora: é como eu me comunico. são as formas de comunicação. quer dizer são os textos que nós encontramos diariamente. ninguém consegue se comunicar a não ser por gênero. imagina se cada um que fosse iniciar uma conversa com alguém sem saber que gênero tá falando. como que tu vai te comunicar com essa pessoa. seria praticamente im: possível a comunicação. senão se utilizar de nenhum gênero não vai haver comunicação. continuando quais são os gêneros orais que nós temos?

10 Aroldo: diálogo, monólogo

11 Professora: que mais. tá o que mais nós temos. entrevista e seminário. só que esses gêneros quando passam da esfera do cotidiano para a esfera pública. bem então os gêneros se dividem em primários e secundários, os gêneros primários são os que usamos no dia a dia e os gêneros secundários são os que usamos na esfera pública. digamos assim que são as entrevistas. o seminário. são gêneros planeja: dos. estrutu: :rados. temos que estudar. temos que elaborar as perguntas. precisamos ter um estudo prévio para poder apresentar um bom seminário

12 Gustavo: perguntas ou tópicos professora

19 Em todos os excertos usamos pseudônimos para referência aos participantes da pesquisa. 
13 Professora: tu podes trabalhar tanto com tópicos quanto com perguntas. agora nós vamos assistir um vídeo. aliás três vídeos com exemplos de gêneros. vamos ver características de gêneros.

Inicialmente foi apresentado o conteúdo da aula programado para essa data. A seguir, o conceito de gênero a partir de exemplos de gêneros orais, observando suas características, estrutura e a linguagem oral em situaçâo de uso.

A análise do fragmento 1 mostra a professora conduzindo os estudantes para 0 conceito de gênero (linhas 03, 05, 06, 07, 08 e 09). Ela introduz o assunto perguntando, a partir de uma abordagem dedutiva, se alguém lembra o que sâo gêneros (linha 03). A partir desse momento, inicia um diálogo com uma das estudantes (linha 05) e exemplifica com esse diálogo fazendo com que os estudantes percebam que se utilizam de gêneros para se comunicarem. Na linha 09, explicita o conceito focalizando a importância do gênero na comunicaçáo. Segundo a teoria dos gêneros do discurso, Bakhtin (2000) nos diz que ao empreendermos uma comunicaçăo, tanto oral como escrita, elegemos um gênero de acordo com a situaçăo comunicativa. Porém, até a linha 10, tanto os alunos quanto a professora reproduzem uma visáo escolarizada dos gêneros orais, expressa por Aroldo na linha 10 como sendo "diálogo, monólogo".

A partir da linha 11, a professora amplia a noçâo de gêneros orais, para além da esfera do cotidiano, apresentando a noçâo de gêneros secundários. Após a análise podemos rever criticamente esse fragmento, pois o conceito de gênero secundário foi apresentado de uma forma muito rígida, sem a mobilidade que o gênero tem e sem considerar que todos os gêneros săo "estruturados", inclusive os primários. Por outro lado, esse modo de falar do gênero encaminha para a construçáo da oralidade como objeto de ensino. E, embora a professora inicie com uma abordagem muito teórica para o nível de ensino, sinaliza, na linha 13, que a discussâo terá continuidade a partir da análise de exemplos dos gêneros a serem estudados.

A partir da observaçâo dos exemplos de gêneros no fragmento 2, alguns estudantes demonstram uma melhor compreensăo sobre os gêneros (linha 06, 13, 14, 20). Na linha 04, a professora solicita mais exemplos de gêneros orais, continua exemplificando (linha 10) e a partir desses exemplos amplia o conceito em foco. A professora utilizou como metodologia a apresentaçăo de vídeos. O primeiro foi de uma conversa informal e o segundo foi uma roda de conversa, como se pode observar no fragmento 2.

Fragmento 2 - Excerto de transcriçâo da aula do dia 26 de maio.

01 Professora: o que vocês observaram nesse vídeo? $(3,4)$

é uma conversa

02 Professora: é um diálogo. conversa informal precisa de uma preparação?

03 Carlos: não

04 Professora: e aí gente o que se conclui a respeito disso. é um diálogo. gênero do cotidiano. gênero primário. vamos ver um outro vídeo. o que que nós vimos de diferente entre esse vídeo e o outro 
05 Aroldo: é um diálogo que é formal

06 Gustavo: professores >altamente< qualificado

07 Professora: e como tu sabe que ele é altamente qualificado

08 Gustavo: pela forma que o cara tá falando. ali ele fala toda a história dele e o que ele é atualmente

09 Carlos: um debate

10 Professora: não. é um gênero roda de conversa. não é debate. quando nós temos que organizar uma roda de conver$\mathrm{sa}^{20}$. temos que passar algumas informações. entre essas informações é a apresentação das pessoas. ele disse o no: me. as [profis: :sões]

11 Aroldo: [>as graduações<]

12 Professora: descobrimos uma característica no gênero roda de conversa que não tem no gênero diálogo informal. é a partir dessa escuta que nós vamos construindo os gêneros. uma outra característica desse gênero tem um [apresentador] mais três pessoas

13 Aroldo: [>apresentador $<]$

14 Gustavo: convidados

15 Professora: um apresentador mais três pessoas. o que também observamos. falando sobre um assunto específico. tem um tema. eles têm um objetivo. outra característica, quando um ffala]

16 Joana: [os outros escutam]

17 Professora: então esse gênero é estruturado. organizado previamente. tem um tema. tem um objetivo. tem uma apresentação dos participantes. o que mais vocês relacionam entre esse gênero primário e o secundário. que diferenças podemos notar além dessas

18 Gustavo: talvez até na forma de se vestir

19 Professora: tá e na linguagem. e é a partir desse estudo dos gêneros que vamos compreender esse aspecto formal do informal. agora nós vamos assistir a um outro vídeo. sempre prestando atenção

20 Aroldo: agora é um >debate político<

21 Professora: prestem atenção bem nesse começo. o::h prestem atenção. o gênero debate ele também é um gênero secundário. agora eu pergunto. o que vocês viram no gênero

20 No gênero roda de conversa, o exemplo apresentado aos estudantes, era um programa televisivo, por isso, foi considerado gênero secundário. Esse conceito está descrito no referencial teórico segundo Dolz e Gagnon (2015). 
roda de conver::sa e no gênero deba::te. qual a diferença que vocês notaram ou as diferenças entre um e outro gênero

22 Aroldo: (>um debate regrado<)

23 Professora: são gêneros secundários os dois. mas ainda tem características diferentes as regras. O debate tem que ter um tema. isso nós temos no gênero roda de conversa e debate. e vamos ter no gênero entrevista e seminário. que nós vamos trabalhar. objetivo. apresentação. essa apresentação. é uma apresentação formal

No decorrer da apresentaçáo dos vídeos, algumas vezes, a professora utilizou o recurso pausa, para que fossem observadas as características, a estrutura e a linguagem que estava sendo usada nesses eventos. Ao observarem e compararem esses gêneros, destacando características de um e de outro gênero, refletiam sobre o uso da língua. Relataram que eram conversas normais entre as pessoas, fazendo referência ao gênero conversa informal e que aconteciam no dia a dia.

Nesse fragmento 2, a professora inicia perguntando o que eles observaram no vídeo (linha 01). Ela faz referência ao gênero diálogo e, ao mesmo tempo, relaciona com conversa informal (linha 02) formulando uma nova pergunta. No momento seguinte (linha 04), descreve o gênero diálogo citando algumas de suas características. Logo após, propóe que assistam a um outro vídeo e, na sequência, indaga o que há de diferente entre eles. Um estudante (linha 05) reconhece a linguagem formal e, na linha 08, outro estudante percebe a qualificaçăo dos convidados pela linguagem. Nesse momento, podemos considerar a importância do uso adequado dos recursos linguísticos na tomada da palavra. Ao relacionar a prática com a teoria, podemos observar o que nos diz a autora Bentes (2010), que quando nos comunicamos com alguém através da fala, fornecemos ao outro uma gama de informaçôes sobre as várias faces da nossa identidade social e também sobre a maior ou menor competência comunicativa.

A professora dá continuidade citando características do gênero apresentado (linhas 15 e 17) e na linha 16 a estudante ressalta a importância do turno de fala, que pode ser tido como aquilo que um falante faz ou diz enquanto tem a palavra, incluindo aí a possibilidade do silêncio (MARCUSCHI, 2006). Na linha 18, quando o estudante percebe elementos năo linguísticos, traz um aspecto exterior presente na comunicaçăo oral, mas compreende que a forma de se vestir influencia no contexto. Os aspectos cinésicos, ou seja, a relaçăo intrínseca entre palavra e corpo săo importantes que sejam discutidos quando da sua percepçăo, pois, é necessário refletir sobre o porquê ele ocorre no discurso. Sendo assim, podemos associar determinadas práticas sociais, que se manifestam na superfície textual, que estăo relacionadas com o discurso oral (MELO; MARCUSCHI; CAVALCANTI, 2012).

Autores como Schneuwly e Dolz (2004, p. 159) nos dizem que "tomar a palavra está em relaçâo íntima com corpo", trazendo-nos a compreensâo que o corpo fala. Portanto, a comunicaçâoo oral vai além da utilizaçâo de recursos linguísticos ou prosódicos, utiliza-se de sistemas semióticos năo linguísticos, desde que convencionalmente reconhecidos como significantes. Entre os meios năo linguísticos, encontra-se o aspecto exterior que inclui as roupas, os disfarces, o penteado, os óculos e a limpeza. 
A aula continua com a apresentaçăo de um terceiro vídeo, quando a professora solicita aos estudantes que prestem atençâo (linha 21), porque mesmo sendo um gênero secundário ainda, possuem características diferentes. Ao perguntar sobre as diferenças, a docente recebe como resposta (linha 22) que é um debate regrado. $\mathrm{Na}$ linha 23, mostra características que săo comuns, assim como as que se diferenciam nos gêneros. Ao mesmo tempo, faz relaçăo com os gêneros entrevista e seminário, que serăo estudados e trabalhados, posteriormente.

Ao finalizar a análise dos fragmentos 1 e 2, foi possível verificar que, apesar de o conceito de gênero ter sido em grande medida abordado de modo teórico, os alunos conseguiram, conjuntamente com a professora, proceder à análise e discussâo de exemplares e aspectos de gêneros orais que vâo além do "diálogo" cotidiano e da espontaneidade.

\section{O ESTUDO DOS RECURSOS (PARA)LINGUÍSTICOS NOS GÊNEROS ORAIS}

O conteúdo da aula foi prosódia e como esses elementos prosódicos e os năo verbais ajudam na composiçâo do sentido. $O$ vídeo selecionado que serviu para análise desses elementos foi do gênero entrevista. Foram apresentados exemplares de entrevista oral e escrita com o objetivo de que identificassem as características dos gêneros nos dois exemplos. Perceberam que a entrevista escrita tinha um tema e observaram o destaque gráfico das perguntas, e, na entrevista oral, recursos como gestos, tom de voz, pausas e movimentos corporais.

Fragmento 3 - Excerto de transcriçăo da aula do dia 28 de maio

01 Professora: nós vamos assistir a entrevista tá. e eu quero que vocês anotem algumas coisas que vocês forem notando na entrevis: :ta. sobre o que nós falamos a respeito da prosódia tá

02 Carlos: e o que, da prosódia

03 Professora: da prosó: :dia. a ento: :na: :ção. as pa: :sas. o que vocês estão notando nessa entrevista ( (apresentação do vídeo))

04 Professora: bem e aí o que nós observamos. o que vocês observaram na entrevista,

05 Aroldo: [que ele é rico] $[\ldots]^{21}$

06 Professora: tá. além disso. a respeito da prosódia. da prosódia o que que nós vimos ali,

07 Aroldo: eles não falaram disso ali professora. $[\ldots]$

21 [...] Símbolo que indica supressăo na transcriçăo dos excertos. 
08 Professora: não. Eles não falaram [tu vais ter que observar]

$$
[\ldots]
$$

09 Aroldo: esse é um (material) bem estranho hhhh

10 Professora: vamos comentar algumas partes. além desses elementos como as pau::sas. que eles fazem en: tre uma fala e outra. Ou entonação da voz. o que mais vocês observaram, nesse vídeo.

11 Aroldo: a comédia

12 Professora: o humor tá, o que mais

$[\ldots]$

13 Professora: tá. mas em matéria da composição desse gênero. tá a caracterís: tica digamos assim. A fala ela tem características que podem se perceber ali naquele vídeo. além das características da fala que outras características se observa ali, $(2,3)$ que outros sinais nos dão esse vídeo na fala, (.) que nos remetem também a informações. (.) alguém perce: :beu: : algum elemento não: : verbal que dá prá perceber no vídeo. o que nós temos ali de elementos não verbais, o que são elementos não verbais, que não se manifestam pela fala

14 Gonzaga: não verbais, gestos

15 Gustavo: oi isso aí. já ía falar gestos, os gestos.

16 Professora: os gestos, muito bem.

17 Gustavo: a forma de gesticular com as mãos

18 Professora: o que mais, o que mais,

19 Gustavo: a piscada de olho

20 Professora: a direção do olhar

21 Gonzaga: o sorrisinho aque: :le. [hhhh]

22 Professora: então junto com a fa: :la e com esses elementos prosódicos que nós vimos. nós temos os elementos não verbais. e esses elementos são muito importantes porque uma pessoa não vai ficar parada olhando e falando assim imóvel ( (a professora reproduz esse comportamento))

$$
\text { [...] }
$$

23 Professora: e que linguagem foi essa da entrevista, gente,

24 Fabiano: (as duas)

25 Mário: formal foi,

26 Professora: tá, mas ela é formal ou informal, 


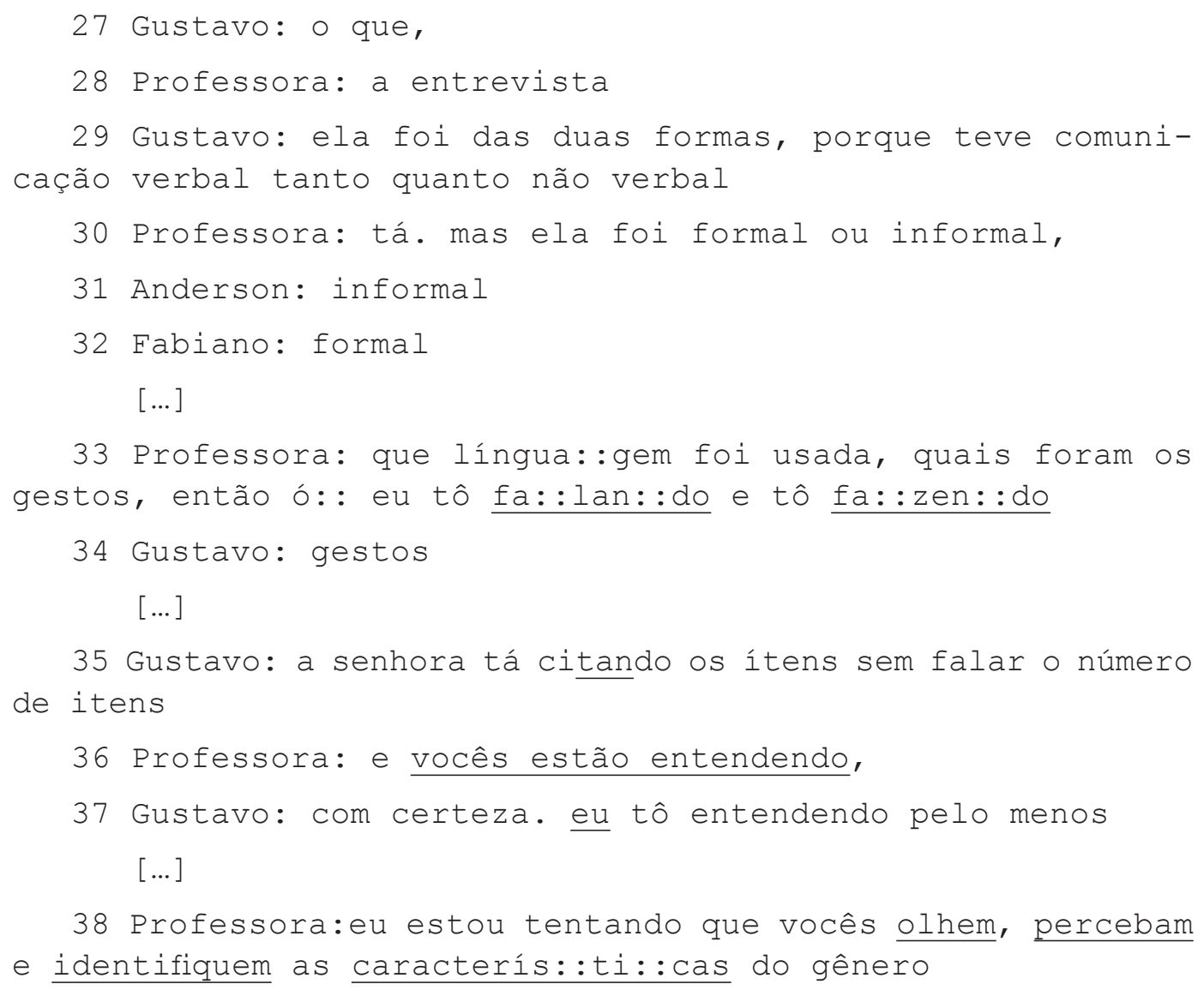

Inicialmente, nota-se um estranhamento por parte dos estudantes (linhas $02 \mathrm{e}$ 15). Os estudantes demoram a perceber qual o objeto de análise na entrevista e falam a respeito da compreensâo (linhas 05, 17 e 19). A professora continua conduzindo-os para que percebam os elementos năo verbais (linha 13) e é nesse momento que se dá essa percepçâo (linhas 14, 15, 17, 19 e 34) e de como esses elementos contribuem na composiçāo do sentido.

Ao introduzir o estudo do gênero através de análise de exemplos, citamos Bentes (2010), que defende que a observaçăo contínua, sistemática e crítica de determinadas práticas contribui para a compreensáo de como os modos de fala podem ser transformados em recursos, de forma a atingir objetivos comunicativos e que estratégias podem ser utilizadas para mobilizar esse envolvimento conversacional. Na linha 38 do fragmento 1 do item 3.2, a professora enfatiza a importância da observaçâo, da percepçấo e da identificaçăo das características que podem ser observadas nos exemplos do gênero.

A análise desse fragmento demonstra como foi conduzida a prática nessa aula, assim como também que açóes foram executadas para conduzir à melhora dessa prática. O efeito de humor năo foi explorado (linhas 11 e 12), com isso, perdeu-se a discussăo, naquele momento do que provocou esse efeito e como isso interfere na construçâo do sentido. Essa análise possibilitou avaliar a açăo pedagógica e refletir sobre como poderia se modificar essa açăo para uma melhor aprendizagem (ver intervençâo da professora na linha 30). 


\section{APROPRIAÇÃO DO GÊNERO ENTREVISTA}

Foi oferecida uma palestra à turma sobre vocaçôes profissionais, visto que os estudantes estavam se preparando para a escolha de suas possíveis profissóes. Essa palestra foi proferida por uma psicóloga com o objetivo de orientar e esclarecer sobre a escolha da profissăo e, ao mesmo tempo, expor os estudantes a uma situaçâo autêntica e năo cotidiana da modalidade oral. Após a palestra, na mesma aula, os estudantes entrevistaram a mesma psicóloga, uma estudante do ensino médio de outra escola e um militar, respectivamente. Nessa data, a aula foi atípica, pois se oportunizou uma situaçăo de uso da modalidade oral complexa que exigiu uma adequaçấo de comportamento social e linguístico diferente do contexto diário.

No fragmento a seguir, a transcriçâo é referente ao momento da entrevista coletiva. ${ }^{22} \mathrm{O}$ estudo do gênero entrevista foi realizado, em aulas anteriores, através de observaçăo em diferentes meios de comunicaçăo, exemplos de uma entrevista televisiva, de rádio e de uma escrita. Ao proporcionar essa observaçăo em meios diferentes, salientaram-se os contextos de produçăo desses gêneros e que recursos podem e devem ser utilizados. Para assumirem o papel de entrevistadores nas situaçóes propostas, os estudantes elaboraram um roteiro de perguntas, mas quando da realizaçăo da entrevista, năo seguiram o que estava previsto, o que sinaliza, conforme mostra o fragmento 1, uma compreensâo da dinamicidade do gênero.

Fragmento 1 - Excerto de transcriçăo da aula do dia 16 de junho

01 Professora: bem gen: te a parte da psicóloga foi o esclarecimento sobre as vocações. a importância da escolha. vamos começar a entrevista ${ }^{23}$

02 Joana: o que te levou a escolher essa profissão,

03 Gustavo: quais os aspectos positivos e negativos da tua profissão,

04 Andressa: porque tu acha que a tua profissão é importante para a sociedade,

05 Cândida: e tu, pretendia realizar essa profissão desde criança. ou foi uma escolha com o passar do tempo,

06 Gustavo: tu na tua profissão. tu te priva de fazer. de debater algum tipo de tema, digamos com teu paciente. isso eu não posso conversar contigo, tem que procurar outro auxílio ou tu debate todo o tipo de tema,

07 Joana: como foi o início da: : tua profissão. quando tu começou a exercer. foi delicado,

22 A entrevista foi considerada coletiva, porque vários estudantes da turma assumiram o papel de entrevistadores. Apesar de haver três entrevistados, cada um foi entrevistado de uma vez. Enquanto um estava no foco, os demais assumiram lugar na plateia.

23 Na transcriçâo do fragmento 1 do item 3.3 foram transcritas apenas as perguntas das entrevistas realizadas pelos estudantes, demonstrando a interaçăo, a dinamicidade e a apropriaçâo do gênero. 
08 Maria: qual é a faixa salarial,

09 Aroldo: alguma coisa. já levou você a desistir da profissão,

10 Gustavo: agora que tu falou. eu formulei uma pergunta. seria assim. prá tu ser uma psicóloga tem que ser uma pessoa calma. tu tem que ter o controle de toda situação, é sim ou não, o que tu achas sobre isso,

11 Andressa: eu andei lendo sobre a psicologia porque é uma área que eu me interesso. me chama atenção. eu li que a maioria são mulheres. apenas dez por cento são homens. porque tu acha que é assim,

12 Professora: nós temos outros convidados também. nós temos a Andreia. estudante do ifsul. é uma escola técnica federal. e ela é aluna do técnico em agropecuária. essa é a Andreia e ela vai responder as perguntas que vocês acharem pertinentes a respeito da escola. do curso. de como funciona.

13 Andreia: eu sou Andreia, tenho 17 anos e tô no $6^{\circ}$ semestre

14 Gustavo: Andreia. bom dia. prazer. eu me chamo Gustavo. a primeira pergunta é assim sobre a agropecuária. tu quis escolher a profissão através da região ou foi uma coisa que já te chamava atenção,

15 Alice: e qual é a faixa de salários,

16 Cândida: nessa tua área. tu tem aulas teóricas ou aulas mais práticas,

17 Cândida: primeiro estuda a teórica prá depois a prática

18 Fabiano: e as pessoas na região estão adotando mais a agricultura ou a pecuária,

19 Gustavo: e tu, tá em que semestre que tu falou,

20 Gustavo: sexto. e alguma vez tu pensou assim. vou desistir. eu não quero mais. vou jogar tudo prá cima e já era,

Esse fragmento demonstra como os estudantes interagiram no momento em que ocuparam a posiçâo de entrevistadores. Năo houve uma apresentaçăo da primeira entrevistada, visto que já havia ocorrido na palestra, mas apenas uma breve contextualizaçăo (linha 01, fragmento 1, item 3.3). Nesse momento, o contexto foi modificado, pois os estudantes ocuparam a posiçâo de entrevistadores. Autoras como Lima e Beserra (2012) defendem a ideia de que um texto oral ou escrito é sempre produzido dentro de um contexto, ou seja, é sempre um texto situado. Portanto, por meio da alteraçấo adequada de seus papéis, os estudantes colaboraram para a mudança de contexto, do gênero e da situaçấo sociointeracional. 
Entre aspectos importantes que săo levados em consideraçăo e merecem ser destacados estâo a compreensăo demonstrada em relaçáo ao uso dos gêneros, a organizaçáo em turno, o tema e o contexto de produçấo. As perguntas da entrevista foram todas direcionadas à profissăo que a entrevistada exerce e năo para a fala anterior sobre as vocaçōes profissionais, como pode ser observado no fragmento 2 deste item (linhas 02 a 11). 0 gênero entrevista foi estudado e discutido, anteriormente, focalizando as características, o tema e a linguagem em uso (linhas 43 a 56, fragmento 1, item 3.2).

No momento da interaçăo face a face, perceberam-se aspectos relevantes na construçăo do sentido, como: a direçăo do olhar, a gestualidade e a expressăo facial. Assim como também a escuta, a mudança de contexto e as perguntas elaboradas sem fugir do tema.

Na entrevista com a aluna de ensino médio, percebem-se mudanças de comportamentos sociais em relaçăo à primeira entrevistada. Um estudante que desempenha o papel de entrevistador (linha 14, fragmento 1, item 3.3), na sua primeira intervençáo com a entrevistada, dirige-se chamando-a pelo nome, cumprimenta-a, apresenta-se e depois formula a pergunta. Ao cumprir essa tarefa, demonstra a apropriaçấo de aspectos relativos às competências comunicativa e discursiva, utilizando-se de recursos linguísticos para desempenhar seu papel social na interaçâo.

\section{APROPRIAÇÃO DO GÊNERO SEMINÁRIO}

No fragmento 1, a seguir, a transcriçăo do excerto demonstra como se deu o estudo do gênero apresentaçâo oral. O estudo desse gênero foi discutido a partir da escolha do uso da linguagem, formal ou informal, e do uso ou năo de gírias nesse gênero. Essa discussâo serviu para demonstrar a importância da adequaçăo do uso da linguagem ao público.

Fragmento 1 - Excerto de transcriçăo da aula do dia 18 de junho

01 Professora: tá Gustavo, tu diz que não pode ter gíria. e se eu for falar para um pú::bli-

02 Cândida: primeiro tem que saber o que tu vai falar

03 Professora: exa: :tamente. tu tem que saber o que tu vai falar e para quem tu vai falar. dependendo do pú::blico até dá para falar alguma gíria. se tu for falar para estudantes de en: sino mé: :dio. de ensino universitá: :rio. aí tu vai ter que adequar a tua fala de acordo com o lugar que tu estas. do contexto que tu estas.

04 Gustavo: imagina vim uma pessoa aqui. e aponta prá um cara e diz assim. e aí feio como tá,

05 Professora: mas nem toda a gíria precisa ser tão chula. uma apresentação oral é preciso ser pensada. estudada. estruturada. para eu delimitar os assuntos mais importantes. porque ela tem um tempo. eu não posso chegar aqui e ficar por um tempo indeterminado falando né. se eu não estruturar. de repente eu posso deixar um tópico importante da minha 
fala. do que eu desejo comuni: car as pessoas. e por fim vai se esgotar esse tempo. então. esse é um dos aspectos que a gente precisa organizar em uma apresentação oral. quando nós vamos fa::zer um trabalho a gente precisa se perguntar algumas coisas. para poder responder e fazer um trabalho que seja interessante. não vou chegar aqui e falar qualquer coisa. porque vamos fazer essa pesquisa, (2, 3) essa é uma das respostas que vocês vão ter que dar na apresentação de vocês. quais os critérios para selecionar o que aprendemos e que merece ser apresentado. são três perguntinhas tá. a primeira coisa é o planejamento do texto (3, 4). um ítem muito importante é a estrutura da exposição oral. ela precisa ter uma sequência. tem uma fase de abertura. uma introdução ao tema. o desenvolvimento. uma conclusão e um encerramento

06 Aroldo: início meio e fim

O fragmento 1 do item 3.4 mostra como se deu o estudo do gênero, partindo de discussăo sobre linguagem formal e informal. A estudante interrompe (linha 02, fragmento 1, item 3.4) referindo-se à importância do tema. A professora traz outros aspectos importantes que devem ser considerados como: a escolha da linguagem adequada ao contexto (linha 03, fragmento 1, item 3.4), a estrutura e o tempo de duraçâo da apresentaçăo oral (linha 05, fragmento 1, item 3.4). Foi disponibilizado material escrito que serviu de apoio para a organizaçăo do seminário, que consistiu em perguntas norteadoras (linha 05, fragmento 1, item 3.4). Ainda na linha 05, do fragmento 1 do item 3.4 a professora ressalta a importância da estrutura e das fases que compóem 0 gênero.

A transcriçăo do fragmento 2 do item 3.4 demonstra o desenvolvimento da apresentaçăo do gênero seminário e evidencia a apropriaçăo desse gênero pelos estudantes.

Fragmento 2 - Excerto de transcriçăo da aula do dia 28 de junho

01 Gustavo: primeiramente bom dia. eu me chamo Gustavo Carvalho. o trabalho será apresentado por mim. Cândida. Aroldo. Wilson e Susana (laponta para cada um dos colegas quando os apresenta)) agora o Aroldo ((aponta novamente indicando o colega)) vai falar sobre o (curso) da farmácia

02 Aroldo: a farmácia de um modo geral. ele é tipo uma faculdade como qualquer outra. tipo chegar lá e fazer um cursinho e vender medicamento. ela é: : tipo. tem que estudar anatomia. várias coisas.

03 Estela: e a farmácia é um curso de graduação que forma profissionais da saúde. e os profissionais da saúde eles têm que ter um pensamento crítico e humanístico para trabalhar com pessoas. 


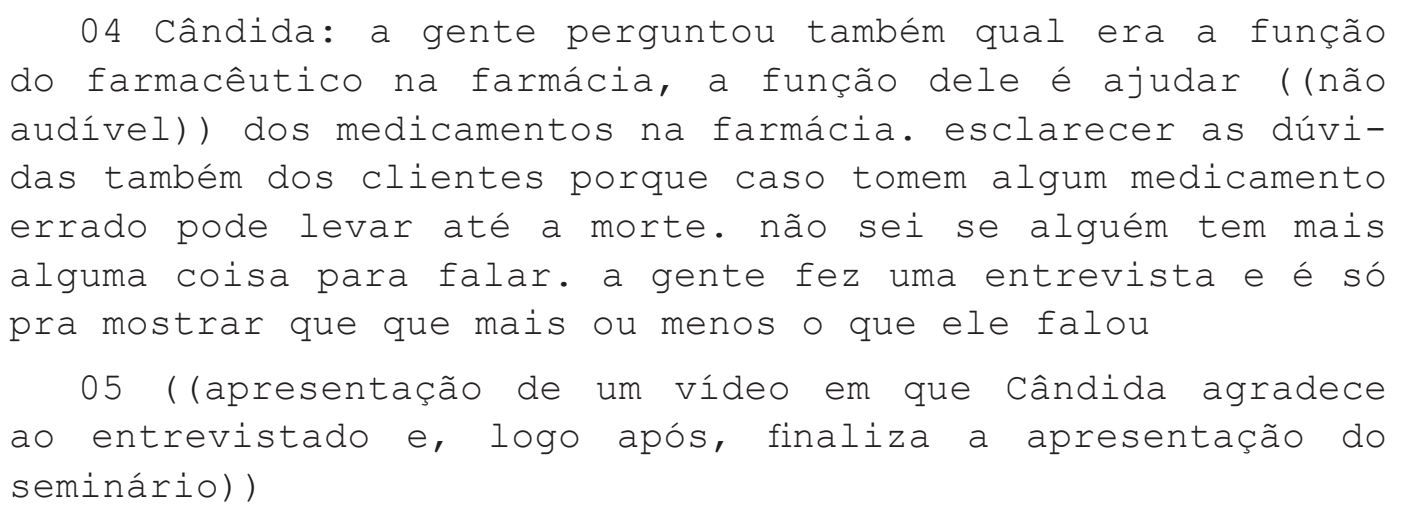

Inicialmente, o aluno responsável pela apresentaçâo do grupo, apresenta-se a si e aos colegas (linha 01, fragmento 1, item 3.5), apontando para cada um deles no momento da apresentaçăo. Ao realizar essa tarefa, demonstra apreensăo e apropriaçăo de elementos náo verbais, conforme foi estudado anteriormente (linhas 36, fragmento 1 , item 3.2). Autoras como Melo, Marcuschi e Cavalcante (2012) defendem a importância de colocar o corpo a serviço da comunicaçăo, pois meios năo linguísticos influenciam fortemente a construçăo do sentido. Junto aos meios năo linguísticos estăo os aspectos paralinguísticos e cinésicos, ou seja, a relaçăo intrínseca entre palavra e corpo. Cabe ao professor chamar a atençấo para esses aspectos e para como podemos utilizá-los como suporte para a comunicaçăo verbal.

Após a apresentaçâo dos componentes, o estudante introduz o tema do seminário e passa a palavra para outro componente do grupo. A seguir, o grupo desenvolve o tema falando sobre o curso (linhas 02 e 03, fragmento 2, acima), o perfil e a funçâo do profissional (linha 04, fragmento 2, acima). Além disso, o seminário é enriquecido com a apresentaçăo de uma entrevista em vídeo, realizada pelo grupo de estudantes. Ao final do fragmento, acontece nova demonstraçáo de apropriaçáo do gênero, pois a estudante que tem o turno encerra a participaçâo do grupo com uma açâo de fechamento (linha 05, fragmento 1, item 3.4). Novamente fica evidenciada a compreensâo dos gêneros entrevista e seminário, pois ambos possuíam as características estudadas e pertencentes a cada um dos gêneros.

Na maioria dos seminários apresentados, observa-se a presença das fases importantes de constituiçăo do gênero. Alguns grupos apresentaram o seminário a partir da leitura de slides e/ou de material escrito de apoio. Ao fazerem a leitura dos materiais, alguns componentes dos grupos leram mal e demonstraram falta de comprometimento com os demais participantes. Contudo, outros componentes assumiram a fala, com isso, sugerindo a importância que o sujeito dá na tomada da palavra (BENTES, 2010,). A seguir, sistematizamos em tabela os resultados da pesquisa, a partir da análise da transcriçâo de excertos. Essa esquematizaçâo tem a finalidade de proporcionar uma melhor visualizaçăo da geraçăo de dados e dos resultados obtidos. 
Tabela I - Resultados da apropriação dos gêneros estudados durante a realização da pesquisa-ação

\begin{tabular}{|c|c|}
\hline Data & \begin{tabular}{c} 
Apropriação dos gêneros \\
\hline $26 / 05 / 2015$
\end{tabular} \\
- Reconhecem a linguagem formal;
\end{tabular}

Fonte: Análise de dados gerados durante a pesquisa-ação.

\section{CONSIDERAÇÕES FINAIS}

Os resultados obtidos na pesquisa demonstram como o estudo dos gêneros orais secundários, neste caso, entrevista e seminário, contribuíram no processo de apropriaçăo desses gêneros. Ao trazer o estudo da modalidade oral, possibilitou-se o uso dos recursos linguísticos de forma mais consciente e reflexiva por parte dos estudantes, além de ter contribuído para que possam compreender que fala e escrita năo se opóem, mas se completam e possuem funcionamentos diferentes. Nossa pesquisa-açăo possibilitou analisar e intervir na apropriaçâo dos seguintes aspectos da oralidade: reconhecer e distinguir linguagem formal e informal; perceber elementos náo linguísticos e sua influência no contexto; reconhecer diferenças e similaridades entre os gêneros secundários; perceber a funçâo da escuta e do turno de fala.

A partir da observaçăo e análise dos excertos, desde a aula inicial até a produçáo final do gênero seminário, houve engajamento por parte dos estudantes, o que legitima a oralidade como objeto de ensino. Na apresentaçăo e estudo do gênero entrevista, fica evidente a legitimaçăo, pois trazem discussóes como a presença do humor e da ironia, os elementos năo verbais, o uso de gíria e que influência esses elementos têm na construçâo do sentido no gênero específico em análise. Tratar a oralidade como objeto de ensino implica identificar, refletir e utilizar os recursos linguísticos e a variedade de usos da língua na modalidade oral em funçăo de práticas sociais específicas, tal como 
evidenciamos na análise de dados concretos de sala de aula.

Ao realizar uma pesquisa de cunho microetnográfico, que busca compreender situaçôes e comportamentos que ocorrem em interaçóes cotidianas ou institucionais, e que, neste caso, focalizou a escola pública, destacamos aspectos que figuram à margem da pesquisa e que precisam ser considerados quando pensamos na pesquisa-açáo. Entre eles, podemos citar: as limitaçôes de recursos materiais, como filmadora e Datashow, que nem todas as escolas da rede pública possuem; a carga horária excessiva dos docentes, que em geral dificulta sua dedicaçăo a um planejamento mais colaborativo e reflexivo sobre a açăo pedagógica; as dificuldades de conduzir para a mudança de práticas em funçăo da realidade institucional ou das próprias crenças do professor. Contudo, acreditamos que as discussôes geradas pela pesquisa-açâo em associaçâo à microetnografia, quando ocorrem, podem contribuir para que mudanças efetivas em objetivos, conteúdos e metodologias possam ser (re)pensadas nas práticas escolares. 


\section{REFERÊNCIAS}

ALMEIDA, M.B.Noçóes básicas sobre metodologia de pesquisa científica. Departamento de Teoria e Gestăo da InformaçăoDTGI/Escola de Ciência da InformaçăoECI/Universidade Federal de Minas GeraisUFMG. Disponível em: <http://mba.eci.ufmg.br/downloads/metodologia.pdf.> Acesso em: maio 2015.

BAKHTIN, M. Estética da criaçăo verbal. São Paulo: Martins Fontes, 2000.

BRASIL. Secretaria de Educaçâo Fundamental. Parâmetros Curriculares Nacionais: Língua Portuguesa. Brasília, 1997.

. Ministério da Educaçăo. PCN + Ensino Médio: orientaçôes educacionais complementares aos Parâmetros Curriculares Nacionais Linguagens, Códigos e suas Tecnologias. Brasília: MEC/SEMTC, 2002.

BENTES, A. C. Linguagem oral no espaço escolar: rediscutindo o lugar das práticas e dos gêneros orais na escola. In: RANGEL, E. O.; ROJO, R. H. R. (Coords.). Língua Portuguesa: ensino fundamental. v. 19. Brasília: Ministério da Educaçăo, Secretaria de Educaçăo Básica, 2010, pp. 129-154.

CAMPOS, E. M.; CARDOSO, P. M.; ANDRADE, S. L. Viva português: ensino médio. 2. ed., Sâo Paulo: Ática, 2013.

DIONE, H. A pesquisa-açăo para o desenvolvimento local. Traduçăo: Michel Thiollent . Brasília: Liber Livro, 2007.

DOLZ, J.; SCHNEUWLY, B.; HALLER, S. O oral como texto: como construir um objeto de ensino.In: ROJO, R.; CORDEIRO, G. S. (Orgs.). Gêneros Orais e escritos na escola. Campinas: Mercado de Letras, 2004, pp. 125-155

; PIETRO, J-F de; ZAHNA, G. A exposiçăo oral.In: ROJO, R.; CORDEIRO, G. S. (Orgs.). Gêneros orais e escritos na escola. 2. ed. Campinas: Mercado de Letras, 2010, pp. 183-211.

; GAGNON, R. O gênero de texto, uma ferramenta didática para desenvolver a linguagem oral e escrita. In: BUENO, L.; COSTA-HÜBES, T. da C. (Orgs.). Gêneros orais no ensino. Campinas: Mercado das Letras, 2015, pp. 23-56.

ERICKSON, F.; SHULTZ, J. “O quando” de um contexto.In: RIBEIRO, B. T.; GARCEZ, P. M. (Orgs.). Sociolinguística interacional: antropologia, linguística e sociologia em análise do discurso. Porto Alegre: AGE, 1998, pp. 142-153.

FRITZEN, M. P. O olhar da etnografia no fazer pesquisa qualitativa: algumas reflexóes teórico-metodológicas. In: FRITZEN, M. P.; LUCENA, M. I. P. (Orgs.). 0 olhar da etnografia em contextos educacionais: interpretando práticas de linguagem. Blumenau: Edifurb, 2012, pp. 55-71.

GARCEZ, P. de M.; BULLA; G. da S.; LODER, L. L. Práticas de pesquisa microetnográfica: geraçăo, segmentaçáo e transcriçăo de dados audiovisuais como procedimentos analíticos plenos. D.E.L.T.A., Sáo Paulo, n. 30, 2, pp. 257-288, 2014.

GOMES-SANTOS, S. N. A exposiçáo oral: nos anos iniciais do ensino fundamental. Săo Paulo: Cortez, 2012. 
LATORRE, A. La investigación-acción: conocer y cambiar la práctica educativa. Barcelo: Graó, 2003.

LEAL, T. F; SEAL, A. G. de S. Entrevistas: propostas de ensino em livros didáticos. In: LEAL, T. F.; GOIS, S. (Orgs.). A oralidade na escola: a investigaçăo do trabalho docente como foco de reflexăo. Belo Horizonte: Autêntica, 2012, pp. 73-94.

LATORRE, A. La investigación-acción: conocer y cambiar la práctica educativa. Barcelo: Graó, 2003.

LIMA, A.; BESERRA, N. Sala de aula: espaço também da fala.In: LEAL, T. F.; GOIS, S. (Orgs.). A oralidade na escola: a investigaçăo do trabalho docente como foco de reflexáo. Belo Horizonte: Autêntica, 2012, pp. 57-72.

LODER, L. L. O modelo Jefferson de transcriçấo: convençōes e debates.In: LODER, L. L.; JUNG, N. M. (Orgs.). Fala em interaçâo social: introduçâo à Análise da Conversa Etnometodológica. Campinas: Mercado de Letras, 2008, pp. 127-161.

LÜDKE, M. e ANDRÉ, M. E. D.A. Pesquisa em Educaçáo: abordagens qualitativas. Sáo Paulo: EPU, 1986.

MARCUSCHI, L. A. Análise da conversaçăo. 5. ed. Săo Paulo: Ática. 2000.

Da fala para a escrita: atividade de retextualizaçăo. Săo Paulo: Cortez, 2001.

Produçáo textual, análise de gêneros e compreensăo. 3. ed. Sâo Paulo: Parábola, 2008.

MATENCIO, M. de L. M. Gênero do discurso e apropriaçăo de saberes: (re)conhecer as práticas linguageiras em sala de aula. Linguagem em (Dis)curso - LemD, Tubarăo, v. 8, n. 3, pp. 541-562, set.-dez, 2008.

MELO, C. T. V. de; MARCUSCHI, B.; CAVALCANTE, M. B. Esclarecendo o trabalho com a oralidade: uma proposta didática. In: LEAL, T. F.; GOIS, S. (Orgs.). A oralidade na escola: a investigaçăo do trabalho docente como foco de reflexăo. Belo Horizonte: Autêntica . 2012, pp. 95-114.

RIBEIRO, B. T.; GARCEZ, P. M. (Orgs.). Sociolinguística interacional: antropologia, linguística e sociologia em análise do discurso. Porto Alegre: AGE, 1998.

ROJO, R. Gêneros do discurso e gêneros textuais: questôes teóricas e aplicadas.In: MEURER, J. L.; BONINI, A.; MOTTA-ROTH, D. (Orgs.). Gêneros: teorias, métodos, debates. Săo Paulo: Parábola, 2005. p. 184-207.

SIGNORINI, I.; CAVALCANTI, M. C. Linguística Aplicada e transdisciplinaridade. Campinas: Mercado de Letras, 1998.

THIOLLENT, M. Metodologia da Pesquisa-Açăo. 18. ed., Săo Paulo: Cortez, 2011.

TRAVAGLIA, L. C. Glossário Ceale. Universidade Federal de UberlândiaUFU/Instituto de Letras e LinguísticaILEEL. Disponível em: <http://ceale.fae.ufmg.br/app/webroot/ glossarioceale/verbetes/competencia-discursiva>. Acesso em: 10 jun 2015. 


\section{ANEXO I}

\begin{tabular}{|c|c|c|}
\hline \multicolumn{3}{|c|}{$\begin{array}{l}\text { RESUMO DAS CONVENÇÕES DE TRANSCRIÇÃO JEFFERSON } 24 \\
\text { ectos de produçáo da fala }\end{array}$} \\
\hline . & (ponto final) & entonação descendente \\
\hline$?$ & (ponto de interrogação) & entonação ascendente \\
\hline , & (vírgula) & entonação intermediária \\
\hline$:$ & (dois-pontos) & prolongamento do som \\
\hline- & (hífen) & corte abrupto na produção vocal \\
\hline Fala & (sublinha) & ênfase em som \\
\hline FAla & (maiúscula) & som em volume mais alto do que o do entorno \\
\hline$>$ fala $<$ & (sinais de maior do que e menor do que) & fala acelerada \\
\hline$<$ fala $>$ & (sinais de menor do que e maior do que) & fala desacelerada \\
\hline$[\quad]$ & (colchetes) & $\begin{array}{l}\text { fala sobreposta (mais de um interlocutor falando } \\
\text { ao mesmo tempo }\end{array}$ \\
\hline \multicolumn{3}{|c|}{ Inspiraçōes/expiraçōes/risos } \\
\hline. hh & (série de h precedida de ponto) & inspiração audível \\
\hline $\mathrm{Hh}$ & (série de h) & expiração ou riso \\
\hline
\end{tabular}

\section{Lapsos de tempo}

medida de silêncio (em segundos e décimos de segundo

\section{Formataçáo}

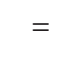

( )

(fala)

((levanta da cadeira))

\section{(sinais de igual)}

(parênteses vazios)

(segmento de fala entre parênteses)

(parênteses duplos) elocuções contíguas

segmento de fala que não pôde ser transcrito

transcrição duvidosa

descrição de atividade não vocal

24 Mantivemos apenas as convençôes utilizadas em nossa pesquisa, em que optamos por uma transcriçăo năo muito fina, mas detalhada o suficiente para que os dados pudessem estar adequados aos propósitos de análise. 